\title{
The Role of Leadership and Strategic Implementation in Humanitarian Agencies in Rwanda: Case of American Refugee Committee
}

\author{
Kirabo Mary", Francis Mwangi Waweru**, Claude Rusibana*** \\ * MBA student, Mount Kenya University, Rwanda \\ ${ }^{* *}$ Lecturer, Mount Kenya University, Rwanda \\ ${ }^{* * * *}$ Senior Lecturer, Mount Kenya University, Rwanda
}

DOI: 10.29322/IJSRP.10.07.2020.p10376

http://dx.doi.org/10.29322/IJSRP.10.07.2020.p10376

\begin{abstract}
The general objective of this study was to assess the role of leadership and strategic implementation in humanitarian agencies in Rwanda. Cross-sectional and descriptive research designs were used. The total population was 247 from which 153 respondents were selected as sample using stratified random sampling technique. Data collection methods involved questionnaire, documentation analysis and interview. Analysis of data was done through SPSS, version 20. As indicated, research findings. The findings revealed that the four models tested using ANOVA for competence of staff, communication of strategic implementation, the amount of resources deployed and the number of people attending training were statistically significant with leadership as measured by inspiring trust, vision creation, in executing strategies and in coaching potentials. The research recommended the use of leadership style which allows for interaction and transformation for strategic implementation.
\end{abstract}

Key Words: Leadership, Leader, Strategy, Implementation, Strategic Implementation, Humanitarian Agency

\section{INTRODUCTION}

Leadership is recognized as important key driver for strategic implementation and acts as major barrier to effect implementation of strategy if it lacks among top leadership of institution. Without effective strategic leadership, the capability of institution to achieve or to sustain the competitive advantage therefore superior performance is greatly constrained (Elenkov, Judge \& Wright, 2005).

According to Mwongela (2013), the concept of strategic implementation is a long process geared towards organization achievements and is time consuming for organizations. The strategic implementation is more costly in terms of time, human efforts and resources to achieve strategic development. According to Hornsby (2000), the concept of leadership is important aspect to achieve strategic implementation if it is well designed. Good leadership within working organization facilitates achievement of vision and mission more effectively. Therefore the management of any organization needs to perform leadership roles like bringing innovation, strategic experts, team members who are committed to bring changes and good decision making as well as effective collaboration in risks taking (Thompson, Strickland \&Gamble, 2010).

This study was carried out in ARC-Rwanda Program. ARC (American Refugee Committee) is a non-profit, non-sectarian, international humanitarian organization providing primary health care, nutrition, WASH, SGBV Protection other related services to vulnerable people uprooted by war and civil conflict. ARC provides assistance to more than one million refugees, displaced persons from Burundi and DRC. These refugees are based in Mahama, Gihembe, Nyabiheke, Kiziba, Kigeme and Mugombwa. All of the refugee camps are occupied by Congolese refugees except for Mahama which is occupied by Burundian refugees. Most of the ARC-Rwanda beneficiaries are me, women and children. ARC-Rwanda receives support from individuals, corporations and foundations, and grants from the US government- BPRM and United Nations agencies such as UNHCR, WFPA, and WFP. ARC- Rwanda started working in Rwanda in 1994 right after the end of the Genocide against the Tutsis in Rwanda. It was helping Rwandan returnees to settle back in their country by giving emergency relief such as shelter and health.

ARC believes that lasting solutions to the world's refugee problems require the direct participation of the local populations in the country affected by crises. ARC links emergency health care assistance with selfhelp training, enabling refugees to become more selfreliant so they may educate others. Training in basic primary health care helps curb the tremendous number of deaths due to unclean water, poor sanitation, and preventable diseases for which immunizations or other preventive methods exist. ARC's methodology is to work on both sides of a border or situation as early as possible to help rehabilitate the community of return and link the level of care and services to those which can be taught/learned/practiced in the home communities. ARC services displaced persons for the long term and helps them voluntarily return home with 
ARC programs that link into longer-term development/sustainable projects. The general objective of the study was to assess the role of leadership to achieve strategic implementation in humanitarian agencies in Rwanda, a case of American refugee committee.

The specific objectives of the study were as follow:

i. To examine how a leader inspires trust among employees in order to contribute to strategic implementation in ARC

ii. To find out how a leader uses vision creation to achieve strategic implementation in ARC.

iii. To assess the extent to which a leader implement strategies with and through employees of ARC.

\section{REVIEW OF RELATED LITERATURE}

Organization leadership presents an important contribution in strategic management process as this determines the organization vision and mission. Within nonprofit making organizations, leadership assists in strategic execution of the stated vision as this is based on the set of behavior to inspire people in formulating organization goals. Leaders play an important role in structuring good leadership through effective leadership to achieve success (Ndunge, 2014).

According to Sami, qamar and Khalid (2011), organization leadership applies to the realization of strategic implementation and achieving strategic plan based on management approach of the organization. Therefore, strategic implementation is driven on the way leaders participate in decision making. To achieve good leadership, the top management contributes in strategic planning, strategic implementation and sometimes initiates towards vision creation, shaping organization vision, setting clear direction and working towards organizational goals and objectives (Hitt, Ireland. \& Hoskisson, 2007).

\subsubsection{Inspires trust}

According to Quigley and James(2007), the concept of trust consists of dainty property of human relationship and indicates the state of power among people and is guided by good conducts in terms of works, speech, achievement and other behavioral aspects of people within social working environment. Being trustful takes time to be happen and it can easily be abolished for some instance.

Inspiring of trust among organization employees consists of aspects of clarity, compassion, characters, contribution as well as consistency. In so many organization, inspiring of trust constitute the significance for people and is applied to assess the individuals beliefs, ability, consistency and integrity (Thompson \& Strickland, 2010; Aosa, 2008).

\subsubsection{Creating the vision}

The concept of vision applies to the anticipated future of organization and is different from organization slogan or mission. Indeed, it describes what the organization intends to achieve at some point (Hsieh
\& Yik, 2005). According to (Taylor, 2007) the concept of vision indicates the image of organization or individual measured in terms of core activities and systematic application. Creating the vision goes through development of strategies to achieve the intended goals and bring the best results. The best way to reach there is to encourage employees through motivation and letting them be the important resources.

According to Robbins and Coulter (2010), vision is about getting from here to there from what is going on today to what must happen tomorrow. A powerful vision is one which challenges the employees to give their best efforts and therefore that vision need to transcend in bottom line because employees are willing and eager to commit to something true, worthwhile and that makes life better for all.

\subsubsection{Strategic execution}

According to Northouse (2013), strategy execution is about transformation of vision, mission and core competences in strategies for an organization excellence. Executing the strategy ensures that leaders use several tools to turn strategy into action. Therefore new strategy must be resourced properly, understood and implemented. Leaders are responsible for making decisions about changes in structure, systems and policies to support their organization's strategic direction. The execution of the strategy is based on facts, rational analysis, intuition, personal experience and imagination. Therefore, executing the strategy is about consistently achieving results with and through others using disciplined processes (Burnes, 2007).

Executing the strategy requires the maximization of organizational potential and ultimately the results by accelerating the alignment of the strategic organizational models and people. Executing the strategy requires that employees be in the right profile and motivation and also be in an environment that is conducive to flawless execution (DFID, 2000).

\subsubsection{Coach potential}

According to Galek (2015), effective leaders develop the leadership potential in others and improve performance through consistent feedback and coaching. The coach possesses a unique standing in organization that is often accompanied by respect and popularity. However, the leader needs to be successful model and coach in many fields of endeavor.

The leader as coach potential establishes the customary leadership model by leading from the bottom-up. Leader as coach potential empowers others in the process of transferring a portion of power that is often reserved for the top rung of traditional leadership. However, the very essence of coaching is an exchange of knowledge between the mentor and the mentee (Russell \& Stone, 2002).

\subsubsection{Theoretical literature on strategic implementation}

According to Thompson, Strickland and Gamble (2010), strategic implementation within business 
organization needs to be projected by top management through designing proper plans of organization activities to achieve a desired outcome. The concept of strategic implementation applies to the organization policies and strategies undertaken based on available budgets to achieve an intended development or programs. Strategic implementation is a continuous process based on proper planning and effective resource allocation (Wheelen \& Hunger, 2008). The implementation of strategies is accomplished through the core competencies among organization staffs which is measured based on traits, capabilities, attributes and skills of staffs which significantly contribute to the organization performance (Aaltonen \& Ikavalko, 2001). Extent of communication within the organization is key pointer to implementation of strategies (Karani, 2009; Wiggill, 2011). In addition, proper utilization of resources is an issue related to effective strategy implementation (Okumus, 2003). The last indicator of strategy implementation is the number of staff who attend trainings (Galek, 2015)

\subsection{Empirical literature review}

The study conducted by Taylor (2007) in London to assess how strategic leadership contribute to the changes within organization and improvement of organization activities. A study done by Pearce and Robinson (2007) in USA about strategic management implementation and organization control revealed that there is a big problem in strategic implementation related to poor coordination of both material, human and capital resources.

The field survey done by Sterling (2003), in USA to assess the strategic implementation showed that most of strategies undertaken to achieve organization activities fail due to market fluctuation, poor organization support, problem related to competition and inappropriate application of organization resources. Abubakar (2011), revealed that most problems hindering strategic implementation process result from unclear structures within an organization. An assessment done by Ahmadi, Salamzade and Daraei (2012), to show the impact of organization culture during the strategic implementation of project in Iranian commercial banks revealed that any type of organization culture influences the implementation of projects. The field survey done by Mbaka and Mugambi (2014), in Kenya to assess the strategy of project implementation more specifically in water sector revealed that the strategic implementation of water project is affected by project management, inappropriate project resource, limited technology and poor technical skills. The study findings also showed that type of leadership style and poor communication skills constitute significant effects on strategic implementation of some projects.
Another study done by Lufthans (2012), at Kellogg about transformation of organizations, transformational leadership is very important on strategy implementation. It puts more emphasis on organizational leaders to provide resources, share the vision, show commitment, and ensure employee involvement in strategy implementation as well as welcoming new ideas.

The theories discussed in this study include; contingency theory and implementation theory.

\subsubsection{Contingency Theory $(\mathrm{CT})$}

This theory was advanced by House (1996) and focuses on contingency approach within the management organization. This theory assumes that there is no specific way of managing, planning, organizing, leading, and controlling organizations. In this theory, the only strategy to be used within organization must be tailored to the specific circumstance faced by an organization. The theory point out the argument related to the managerial decision making which must be applied based on situation and market condition. A strategic leader takes suitable actions based on the aspects that are most important to the current situation. The implication of this theory to the current study is that leaders need to include staff members in sharing decision and take strategic policies to achieve strategic objectives. Within ARC, there is need for coordination, participation and teamwork to allow the organization to implement strategies.

\subsubsection{Implementation theory (IT)}

The implementation theory is the theory first advanced by Jackson (1991) to show how organization implement strategies through systematic design of techniques, exchange of information, allocation of resources and proper decision making to achieve the performance. This theory is of great importance as it indicates the relevance of designing effective strategies and how the strategies match with organization needs. Hence, customers' satisfaction is achieved. The implication of implementation theory is that the achievements within organization are reached through cooperation between organization top management and employees as ingredient to achieve the success.

\subsection{Conceptual framework}

The main variable of interest in this study consists of independent variable which is role of leadership as it is measured by inspire trust, creation of the vision, execution of strategy and coach potential. However, strategic implementation in ARC as dependent variable and it is determined by the level of competence of staff members, extent of communication process, and amount of capital resource and number of people who attended trainings. 


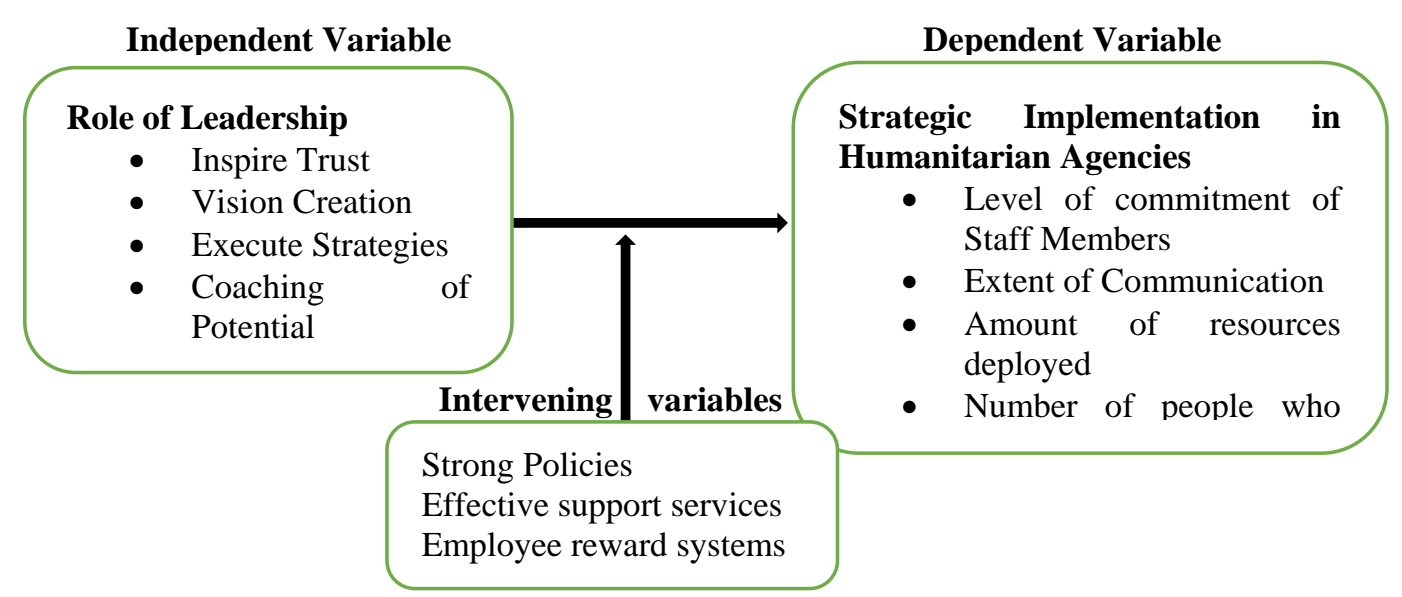

Figure 1: Conceptual framework

Source: Researcher, 2020

\section{RESEARCH METHODOLOGY}

\subsection{Research Design and Population}

A cross section and descriptive research design was used as this remain effective in bringing clear description of the situation as it exist naturally. The study was conducted in Rwanda, in six refugee camps within five districts (Mahama refugee camp-Kirehe, Nyabiheke refugee camp-Gatsibo, Gihembe refugee camp-Gicumbi, Kiziba refugee camp-Karongi, Kigeme and Mugombwa refugee camp-Huye) and Kigali city in Gasabo district at ARC Country Head Office. Data related to the role of leadership in strategic implementation in humanitarian agencies covered the period from 2016 to 2018.

The target population of this study was the top level management team who were given interview while Table 1: Population and Sample Size

\begin{tabular}{llll}
\hline Category of population & Population & Proportion & Sample size \\
\hline Top level management team & 6 & 0.024 & 4 \\
Officials of ARC in senior management & 18 & 0.073 & 11 \\
Officials of finance department & 9 & 0.036 & 6 \\
Leadership teams & 23 & 0.931 & 14 \\
Officials in program department & 191 & 0.773 & 118 \\
Totals & 247 & & 153 \\
\hline
\end{tabular}

\section{Source: Field data, 2020}

\subsection{Data Collection and analysis}

In conducting this research, face to face interview was conducted for the top level management of American Refugee Committee. A structured questionnaire with closed-ended questions was administered to other staff in ARC.

The completed questionnaire was edited for completeness and consistency. Questionnaires were checked for errors and omissions. Data presentation and analysis was done using SPSS (Statistical Package for Social Science) version 20. Qualitative data were analyzed using content analysis to generate qualitative reports which were presented in a continuous meaning.

\section{RESEARCH FINDINGS AND DISCUSSION}

4.1 Demographic characteristic of respondents officials of ARC in senior management section, finance, leadership team and Programs department who were given questionnaire. In total, the target population was 247.

\subsection{Sampling Design}

Yamane (1967) formulae was used to determine the sample size as follow:

$$
n=\frac{N}{1+N e^{2}}=\frac{247}{1+247 * 0.05^{2}} \approx 153
$$

Where, $\mathrm{n}=$ is sample size $\mathrm{N}=$ is the total population $\mathrm{e}=$ is Sampling error which is 5\%. Therefore, the sample size is computed as 153 respondents. Stratified random sampling was used to select sample elements.
Majority of respondents $85(55.6 \%)$ were male while $68(44.4 \%)$ were female. In terms of age group, research findings showed that $77(50.4 \%)$ of respondents were aged between 31-40 years; 38 (24.8\%) aged between 41-50 years; 26 (17.0\%) aged between 18-30 years while 12(7.8\%) aged between 51-60years.

In terms of education level, research findings showed that $85(55.6 \%)$ have completed diploma and $56(36.6 \%)$ have completed bachelor's degree while $12(7.8 \%)$ have completed masters' degree. Based on working experience, information collected from ARC revealed that $112(73.2 \%)$ of surveyed respondents have been working at ARC for the period between 3-5 years. Another 17(11.1\%) for the period between 12years, $15(9.8 \%)$ worked at ARC less than one year 
while $9(5.9 \%)$ have working at ARC more than five

years

4.2 Presentation of findings

Table 2: Respondents' views on Leadership

\begin{tabular}{|c|c|c|c|c|c|c|}
\hline & \multicolumn{2}{|c|}{ Yes } & \multicolumn{2}{|c|}{ No } & \multicolumn{2}{|c|}{ PNS } \\
\hline & $\mathrm{n}$ & $\%$ & $\mathrm{n}$ & $\%$ & $\mathrm{n}$ & $\%$ \\
\hline \multirow{3}{*}{ Do you have trust in ARC Leadership } & 13 & 87. & 1 & 7. & & 4. \\
\hline & 4 & 6 & 2 & 8 & 7 & 6 \\
\hline & 14 & 96. & & 3. & & \\
\hline ARC leadership leads the employees towards the organization's Vision & 7 & 1 & 6 & 9 & 0 & 0 \\
\hline \multirow{3}{*}{ Strategies in ARC were executed as a result of effective leadership } & 14 & 96. & & 3. & & \\
\hline & 8 & 7 & 5 & 3 & 0 & 0 \\
\hline & 14 & 97. & & 2. & & 0 . \\
\hline \multirow{4}{*}{$\begin{array}{l}\text { ARC-Leadership hires the rightful people to fill strategic positions } \\
\text { ARC leadership coached your potential to implement the organization } \\
\text { strategies }\end{array}$} & 9 & 4 & 3 & 0 & 1 & 7 \\
\hline & 14 & 93. & & 4. & & 2. \\
\hline & 3 & 5 & 7 & 6 & 3 & 0 \\
\hline & 14 & 96. & & 3. & & \\
\hline ARC leadership helps you to achieve ARC's vision as its employee & 7 & 1 & 6 & 9 & 0 & 0 \\
\hline
\end{tabular}

PNS=prefer not to say

\section{Source: Field data, 2020}

As shown in Table 2, different responses were obtained from the respondents in regard to trust, vision, strategic execution, hiring and coaching. The majority of the respondents indicated by $87.6 \%$, indicated they have trust in ARC leadership with only $7.8 \%$ say they do not have trust with the leadership. On whether ARC leadership leads the employees towards the organization's vision, $96.1 \%$ of the respondents indicated yes and $3.9 \%$ said no. similar results were obtained with majority of respondents indicating yes when asked whether strategies in ARC were executed as a result of effective leadership (96.7\%), on whether ARC hires the right people (97.4\%), on whether ARC leadership coach potential (93.5\%) and lastly, on whether ARC leadership helps you to achieve ARC's vision (96.1\%).

Table 3: Ways in which leadership inspire trust

\begin{tabular}{|c|c|c|}
\hline Response & Frequency & Valid Percent \\
\hline $\begin{array}{l}\text { Strong Human } \\
\text { Resources }\end{array}$ & 21 & 13.7 \\
\hline $\begin{array}{l}\text { Introducing workers' } \\
\text { union }\end{array}$ & 38 & 24.8 \\
\hline $\begin{array}{l}\text { Social interaction with } \\
\text { lower staff }\end{array}$ & 94 & 61.4 \\
\hline Total & 153 & 100.0 \\
\hline
\end{tabular}

Source: Field data, 2020

As indicated in Table 3, social interaction by leaders was the main contributing factor to inspiring trust. Such findings were in line with what Lufthans (2012) emphasized that leaders should be able interact with the juniors and ensure their participation.

Results displayed in Table 4 below echo similar results by Lufthans (2012) who pointed out the need for visionary leaders in implementing strategic goals of an organization. The discussion by Hsieh and Yik (2005) revealed that leaders are supposed to provide vision at all times to their followers. Hence, there is need for more visionary leaders towards strategic implementations. Similarly, Robbins and Coulter (2010) pointed this out that leaders without an objective will have no motivation to perform and will mislead the employees and the organization at large.

Table 4: Respondents' views on role of leadership on organization's vision

\begin{tabular}{|c|c|c|c|c|c|c|}
\hline & \multicolumn{2}{|l|}{ SA } & \multicolumn{2}{|l|}{ A } & \multicolumn{2}{|l|}{$\mathrm{D}$} \\
\hline & $\mathrm{n}$ & $\%$ & $\mathrm{n}$ & $\%$ & $\mathrm{n}$ & $\%$ \\
\hline Strategic goals by leaders of ARC lead the employees towards the & 12 & 83. & & 13. & & 3. \\
\hline organization's vision & 8 & 7 & 20 & 1 & 5 & 3 \\
\hline & & 18. & 11 & 77. & & 3. \\
\hline Policies by leaders lead the employees towards the organization's vision & 28 & 3 & 9 & 8 & 6 & 9 \\
\hline
\end{tabular}


Clear objectives set by leaders lead the employees towards the organization's

1066.

32.

2. vision

$\begin{array}{llllll}1 & 0 & 49 & 0 & 3 & 0\end{array}$

$\mathrm{SA}=$ strongly agree, $\mathrm{A}=$ agree, $\mathrm{D}=$ disagree

Source: Field data, 2020

The respondents were requested to indicate the level of agreement on various statements on the role of leadership on organization vision and the results are shown in Table 4. It is clear from the table that only a few of the respondents disagreed with the three statements with only $3.3 \%, 3.9 \%$ and $2 \%$ of the respondents respectively.

Table 51: Model Summary between Role of Leadership and Level of Competence of Staff

\begin{tabular}{|c|c|c|c|c|c|c|c|}
\hline Model & $\mathrm{R}$ & R Square & Adju & Square & Std & rror of the & Estimate \\
\hline 1 & $.905^{\mathrm{a}}$ & .819 & .814 & & .18 & & \\
\hline a. Pred & tors: (Consta & Coaching, Trust, & Vision & uting & & & \\
\hline Model & & Sum of Squares & $\mathrm{df}$ & Mean S & are & $\mathrm{F}$ & Sig. \\
\hline & Regression & 22.093 & 4 & 5.523 & & 167.370 & $.000^{\mathrm{b}}$ \\
\hline 1 & Residual & 4.884 & 148 & .033 & & & \\
\hline & Total & 26.977 & 152 & & & & \\
\hline
\end{tabular}

a. Dependent Variable: Competence

b. Predictors: (Constant), Coaching, Trust, Vision, Executing

\begin{tabular}{lllllll}
\hline \hline Model & & \multicolumn{2}{l}{ Unstandardized Coefficients } & $\begin{array}{l}\text { Standardized } \\
\text { Coefficients }\end{array}$ & t & \\
\cline { 3 - 5 } & & $\mathrm{B}$ & Std. Error & Beta & \\
\hline & (Constant) & .287 & .081 & & 3.566 & .000 \\
& Trust & .400 & .080 & .458 & 4.998 & .000 \\
1 & Vision & .082 & .137 & .266 & -.600 & .008 \\
& Executing & .610 & .150 & .147 & 4.074 & .000 \\
& Coaching & -.103 & .160 & .133 & -.641 & .523 \\
\hline \hline
\end{tabular}

a. Dependent Variable: Competence

Source: Field data, 2020

As shown in Table 5, the AnR-squared is 0.814 which shows that $81.4 \%$ of the changes in the competence of staff is influenced by the role of leadership in inspiring trust, vision creation, in executing strategies and in coaching potentials. According to Table 4.24, the model between role of leadership and competence of staff was found to be significant since the $\mathrm{p}<0.05$. Only coaching of potential was found not to be
4.3 Extent to which leader implements strategies with and through employees of ARC

When assessing the extent to which leader in ARC implement strategies through employees, multiple regression analysis as well as analysis of variance (ANOVA) were used. a. Predictors: (Constant), Coaching, Trust, Vision, Executing 
Table 6: Model Summary between Role of Leadership and Extent of Communication

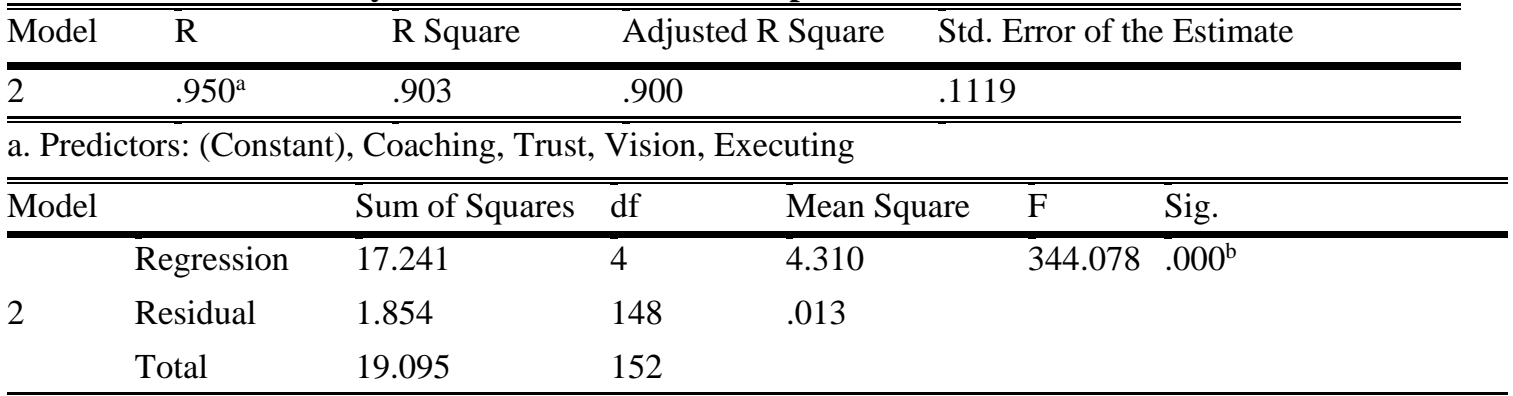

a. Dependent Variable: Communication

b. Predictors: (Constant), Coaching, Trust, Vision, Executing

\begin{tabular}{lllllll}
\hline \hline Model & & \multicolumn{2}{l}{ Unstandardized Coefficients } & $\begin{array}{l}\text { Standardized } \\
\text { Coefficients }\end{array}$ & $\mathrm{t}$ & Sig. \\
\cline { 3 - 5 } & & $\mathrm{B}$ & Std. Error & Beta & \\
\hline \multirow{2}{*}{2} & (Constant) & .490 & .050 & & 9.878 & .000 \\
& Trust & .036 & .049 & .135 & .720 & .473 \\
& Vision & .364 & .084 & .223 & 3.031 & .003 \\
& Executing & .605 & .092 & .905 & 6.555 & .000 \\
& Coaching & .353 & .099 & -.231 & 3.577 & .005 \\
\hline \hline
\end{tabular}

a. Dependent Variable: Communication

\section{Source: Field data, 2020}

Table 6 shows that the AnR-squared was found to be 0.900 showing that $90 \%$ of the communication of strategic implementation in the humanitarian agencies are influenced by the role that the leaders play. Muhoro (2011) found strong correlation exist between leadership role and the effective flow of communication within an organization setting. The ANOVA results showed that the significance value is
0.000 , which is less than 0.05 . Therefore, the model is statistically significant in predicting how the role of leadership in inspiring trust, vision creation, executing strategies and coaching potentials influence communication of the strategies. Ahmadi, Salamzade and Daraei (2012) suggested the need to put an organizational culture that promotes effective communication in the implementation of strategies. 
Table 7: Model Summary between Role of Leadership and Resources Deployed

\begin{tabular}{|c|c|c|c|c|c|c|}
\hline Model & $\mathrm{R}$ & R Square & & djusted R Square & $\begin{array}{l}\text { Std. } \\
\text { Esti }\end{array}$ & $\begin{array}{l}\text { Error } \\
\text { ate }\end{array}$ \\
\hline 3 & $.911^{\mathrm{a}}$ & .829 & & 25 & .192 & \\
\hline a. Pred & ctors: (Const & t), Coaching, Trust & t, Vision, Ex & cuting & & \\
\hline Model & & Sum of Squares & $\mathrm{df}$ & Mean Square & $\mathrm{F}$ & Sig. \\
\hline & Regression & 26.632 & 4 & 6.658 & 179.947 & $.000^{\mathrm{b}}$ \\
\hline 3 & Residual & 5.476 & 148 & .037 & & \\
\hline & Total & 32.108 & 152 & & & \\
\hline $\begin{array}{l}\text { a. Depe } \\
\text { b. Pred }\end{array}$ & $\begin{array}{l}\text { ident Variab } \\
\text { ctors: (Const }\end{array}$ & $\begin{array}{l}\text { Resources } \\
\text { t), Coaching, Trus }\end{array}$ & t, Vision, Ex & cuting & & \\
\hline Model & & Unstandardized C & Coefficients & $\begin{array}{l}\text { Standardized } \\
\text { Coefficients }\end{array}$ & $\mathrm{t}$ & Sig. \\
\hline & & B & td. Error & Beta & & \\
\hline & (Constant) & .119 & 085 & & 1.393 & .169 \\
\hline & Trust & .581 & 085 & .606 & 6.852 & .000 \\
\hline 3 & Vision & .063 & 145 & .208 & .434 & .665 \\
\hline & Executing & .853 & 159 & .925 & 5.377 & .000 \\
\hline & Coaching & -.499 & 170 & -.640 & -2.937 & .004 \\
\hline
\end{tabular}

a. Dependent Variable: Resources

\section{Source: Field data, 2020}

The third dependent variable of interest in this research was to investigate whether the amount of resources deployed do affect the strategic implementation. Table 7 reveal the AnR-squared between the role of leadership and the amount of resources deployed was found to be 0.825 . This implied that $82.5 \%$ of the amount of resources

deployed are influenced by the role of leadership in ARC. Similar results were obtained by Pearce and Robinson (2007) who found that resource coordination is highly influenced by the leadership effectiveness. Mbaka and Mugambe (2014) also found significant relationship between the leadership and resource availability in an organization.

Table 4.8: Model Summary between Role of Leadership and Training

\begin{tabular}{|c|c|c|c|c|c|c|c|}
\hline Model & $\mathrm{R}$ & R Square & Adju: & Square & Std. B & or of the & mate \\
\hline 4 & $.851^{\mathrm{a}}$ & .724 & .717 & & .2465 & & \\
\hline a. Pred & ctors: (Consta & , Coaching, Trus & , Visic & cuting & & & \\
\hline Model & & Sum of Squares & $\mathrm{df}$ & Mean & Square & $\mathrm{F}$ & Sig. \\
\hline & Regression & 23.599 & 4 & 5.900 & & 97.063 & $.000^{\mathrm{b}}$ \\
\hline 4 & Residual & 8.996 & 148 & .061 & & & \\
\hline & Total & 32.595 & 152 & & & & \\
\hline
\end{tabular}

a. Dependent Variable: Training

b. Predictors: (Constant), Coaching, Trust, Vision, Executing

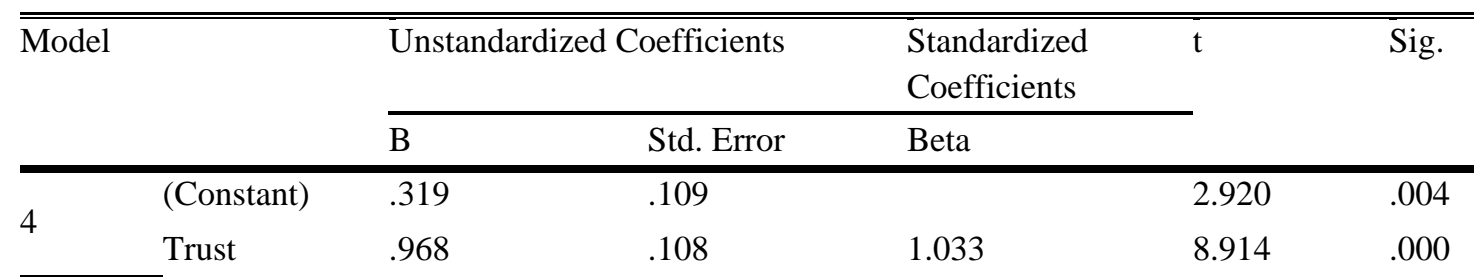




\begin{tabular}{llllll}
\hline Vision & .096 & .186 & .483 & .518 & .605 \\
Executing & .246 & .203 & .441 & 1.209 & .228 \\
Coaching & -.541 & .217 & -.901 & -2.399 & .018 \\
\hline \hline
\end{tabular}

a. Dependent Variable: Training 
The last variable of interest in this research in relation to dependent variable was the number of people attending training. As shown in Table 4.8, the AnRsquared that was obtained was 0.717 . This showed that $71.7 \%$ of the number of people attending training was influenced by the role of leadership. Galek (2015) found that leadership style has a great significance to the training opportunities provided to employees in an organization.

As shown by the ANOVA analysis, the role played by the leadership in ARC has significant influence on the number of people attending training $(\mathrm{p}<0.05)$. According to the results, vision creation $(\mathrm{p}=0.605)$ and executing strategies $(\mathrm{p}=0.228)$ were found to have no significant influence on the number of people attending training since their $\mathrm{p}$-values were more that $5 \%$. However, inspiring trust has a positive and significant influence $(\mathrm{p}<0.05)$ while coaching of potential has a negative and significant influence $(\mathrm{p}<0.05)$ on the number of people attending training. Mbaka and Mugambi (2014) found out that coaching has a positive and significant influence on training. In addition, Lufthans (2012) found that trusted leadership provide ground for training of employees.

4.3Thematically presentation of the study findings 4.3.1The style of leadership used in implementation of strategy in ARC

As indicated by one of management team, ARC uses democratic style of leadership and participative style of leadership which assist the institution in achieving or implementing its strategies. Taylor (2007) in his research when assessing the strategic leadership and how this contribute to organization changes within working environment, showed that committed leaders ensure organization change is important and is measured in terms of improvement in organization activities. To achieve strategic implementation, organization leaders need to apply effective communication both internally and externally to its employees by using an open style of management so that they build the development of corporate culture among employees

4.3.2The challenges faced by leaders in strategic implementation

When assessing the challenges faced by leaders in strategic implementation, one of the team members said that leaders encounter problem related to monitoring, evaluation practices and inefficiency of internal audit to achieve strategic implementation. Insufficient of link between strategy, structure, management information communication system as well as failure in leadership skills constitute the negative impact on strategic implementation. Most organizations are currently challenged with ineffective strategic formulation to achieve the implementations, to allocate resources and undertake the match between strategies, structure and relationship. Pearce and Robinson (2007) study in USA showed that most management organizations are challenged with lack of effective coordination and support from strong management team as lack of resistance from low level of the management and then poor planning.

4.3.3 Way to overcome challenges to ensure appropriate strategic implementation of activities The research findings from the management of ARC showed that, the management is trying to motivate managers towards role performance and participation in internal check and control of organization activities which may bring about implementation of strategies.

\section{CONCLUSION AND RECOMMENDATIONS}

Based on research findings, the leadership which is reliable, leadership which is determined by good listeners and understanding and leadership which encourages approachability may ideally lead to strategic implementation in humanitarian agencies. As indicated, and institution having strong human resources with skills and experience, is more likely to achieve strategic implementation, introduction of workers' union may lead to work performance and implementation of strategies. The findings showed that encouraging social interaction with lower staff is more helpful for institution to achieve strategic goals and objectives.

The observation in this research is that if leaders set policies which assist the employees achieve organization goals, it can result into strategic implementation. The general conclusion is that hiring the right people to fill strategic position may bring about strategic implementation.

The recommendation regards to the commitment towards strategy implementation by senior management team is a vital ways of achieving organization goals and objectives. Researcher recommend the management of ARC to provide more efforts and loyalty to achieve strategic implementation. However, they need to influence organization employees towards having ideas for strategic implementation. At ARC, It is important to regularly track the level of strategic implementation, work towards changes to achieve strategic implementation. In addition, ARC, need to apply the approach of rewards among its employees to achieve the desired performance and incorporate high rank of employees in strategic design and implementation

\section{BIBLIOGRAPHY}

[1]. Aaltonen, P. and Ikavalko, H. (2001). Implementing Strategies Successfully. A Paper Presented at the XII World Productivity Congress: San Jose, CA.

[2]. Akinbile LA, Oladoja MA, Awoniyi FM and Adisa BO . (2006). Effects ofcommunity participation on perception of sustainability of rural water projects in Oyun Local Government Area of Kwara State, . Nigeria.

[3]. Aosa, E. (2008). The nature of strategic management in Kenya, Unpublished Project . Nairobi: University of Nairobi.

[4]. Asian Development Bank . (2006). Third water supply and sanitation project-participatory, 
consultative and empowering. New Delhi : India:.

[5]. Bailey, K. (1994). Methods of Social Research. New York: Division of Macmillan.

[6]. Boulding, K. (2006). The Economics of the Coming Spaceship Earth, in H.Jarrett (ed.), Environmental Quality in a Growing Economy,. Johns Hopkins University Press,.

[7]. Boyatzis, R. (2012). The Competent Manager: A Model for Effective Performance, . John Wiley and Sons, : New York, NY.

[8]. Briggs,J and Coleman,S. (2004). Research methods for Business:A skill building approach. 5th edition. New York: jhon Wiley \& Sons,Ltd.

[9]. Burnes, B. (2007). Managing change a strategic approach to organizational dynamics. (4th Ed.). . Cambridge:: Prentice Hall.

[10]. Capon, C. (2008). Understanding Strategic Management. . England: : Prentice Hall.

[11]. Cooper, K. and Schindler, P. (2006). Business Research Method. New Delhi, : India: Tata division of Thomson Learning.

[12]. Curtis, D. (2005). Power to the people: Rethinking community development. UK: London.

[13]. Daft, R. (2009). Management (9th Edition) . USA: South Western, Cengage Learning.

[14]. De Beer, F. (2008). Community development and beyond: Issues, structure and procedures. Pretoria: : Van Schaik.

[15]. Deverill, P. (2001). Sharing it our -introducing water demand strategies for small towns (London and Loughborough, UK: Water and Environmental Health). UK: London.

[16]. DFID. (2000). Strategies for achieving the International Development Targets: Addressing the Water Crisis - Healthier and more productive lives for the people. Ney York: USA.

[17]. Dudeswell, E. (2009). Cosultation and partnership are factors for success. One Country, 11(1): 1-5.: Kenya.

[18]. Elenkov, D. S., Judge, W., and Wright, P. (2005). Strategic Leadershipand Executive Influnece: An International Multi-Cluster Comparative Study. Strategic Management Journal, , pp 26: 665-682.

[19]. Elwak, R. (2014). Challenges of Strategy Implementation At Mazars Kenya. Nairobi, KE: Kenya: MBA Thesis University Of Nairobi.

[20]. Field, C. (2005). Qualitative research methods, theory and practice. $2^{\text {nd }}$ Ed. USA: New York.

[21]. Galek, K. (2015). The value of servant leadership in coaching. Department of Servant Leadership Studies, . Columbus State University, : Columbus, GA.

[22]. Ghai, D., and Vivian, J. (2014). Grassroots environmental action: people's participation in sustainable development. London: : Routledge.

[23]. Gorre-Dale E, De Jong D and Ling, J. . (2004). Communication in water supply and sanitation: resource booklet. International Water and Sanitation Centre, pp132-143.

[24]. Hitt, M. Ireland, D. and Hoskisson, R. (2007). Strategic Management: Competitiveness and Globalization, 7th edition. . Ohio: Thomson/South Western.

[25]. Hornsby. (2000). New roles of leaders: a step by step guide to competitive advantage . USA: Hillsboro press.

[26]. Hsieh, T. and Yik, S. (2005). Leadership as the starting point of strategy. McKinsey Quarterly, , pp 1: 67-76.

[27]. Hussey, D. (2008 ). Strategic management: from theory to implementation, 4th edition, . Oxford: Butterworth Heinemann.

[28]. IEA. . (2007 ). A rapid assessment of Kenya's water, sanitation and. Institute of Economic Affairs . Kenya.

[29]. James C. Collins and Jerry I. Porras, (2014). Built To Last:Successful Habits of Visionary Companies. (New York: : Harper Business, 235.

[30]. John. (2002). how is strategy formed in organization? a multi-disciplinary taxonomy of strategy making approaches,. The journal of behavioral and applied management 3(1), pp 64-67.

[31]. Karani, T. (2009 ). Strategy Implementation at Kenya Electricity Generating Company (KENGEN) Ltd. . University of Nairobi, : Management Research Project.

[32]. Keter, A. (2015). Challenges Of Strategy Implementation In The Telecommunication Industry In Kenya: A Case Of Safaricom Limited: (Doctoral Dissertation, United States International University-Africa).

[33]. Kothari, C. (2007). Research methodology and techniques. 2nd edition p56. New York: New Dehli.

[34]. Lufthans, G. (2012). Transforming organizations to transform society. In Kellog leadership studies project. Transformational leadership working papers,. University of Maryland: : The James McGregor Burns Academy of leadership.

[35]. Mugenda, O and Mugenda,G. (2003). Research Methods. Quantitative and approaches,. Nairobi: Laba Graphics services Ltd.

[36]. Muhoro, J. (2011). The effect of leadership in strategic change implementation in Telkom Kenya, Unpublished MBA Project, . Kenya: University of Nairobi.

[37]. Mwongela, E. (2013). Factors affecting strategy implementation at Kenya National Audit Office, Unpublished MBA Project,. Kenya: Kenyatta University.

[38]. Naiga, R., Penker, M. and Hogl, K. (2012). From supply to demand driven water governance: challenging pathways to Safe Water Access in Rural Uganda. Kampala: Uganda.

[39]. Ndunge, W. (2014). Strategic leadership and change management practices at the Kenya 
wildlife service, Unpublished MBA Project, . Kenya: University of Nairobi.

[40]. Njoh, A. (2003). Self-help water supply in Cameroon Lessons on community participation in public works projects. Cameroon: The Edwin Mellen Press.

[41]. Northouse, P. (2013). Leadership Theory and Practice. SAGE Publications, Thousand Oaks, :California.

[42]. Okumus, F. (2003). A Framework to Implement Strategies In Organizations. Management Decisions, , pp 41(9), 31-45.

[43]. Opportunity Interational. (2012). Provision of microfinance services in the developing world. IL.Retrived fromhttp://www.Opportunity.org: Oak Brook.

[44]. Ostrom E, and Ahn T. ( 2003). Introduction. In Foundations of Social Capital, Ostrom E, Ahn T (eds). Edward Elgar Publishing, Ltd.: Cheltenham, : UK.

[45]. Pearce, A. \& Robinson, B. (2007 ). Formulation, implementation and control of competitive strategy, 9th edition. . Boston, MA: : McGrawHill Irwin.

[46]. Pearce, A. and Robinson, R. (2007). Strategic Management: Implementation and Control, 3rd edition,. Boston: Richard D. Irwin McGrawHill,: USA.

[47]. Quigley and James, H. (2007). Trust - An Essential Asset: Creating Individual and Corporate Value. The Raytheon Lectureship in Business Ethics, . Waltham:: Bentley College, pp. $1-24$.

[48]. Robbins, G. and Coulter, M. (2010). Functional management and organization performance. (1 st Ed.). USA: Pearson publishers.181.

[49]. Roodt, M. (2001). Participation, civil society and development. In KJ Coetzee, J Graaff, F Hendricks \& G Wood (eds.), Development: Theory, policy, and practice. Oxford : . Coetzee: Oxford University Press.

[50]. Russell, R. F., and A. G. Stone. (2002). A review of servant leadership attributes: developing a practical model. . Leadership \& Organization Development Journal, , pp 23, 145.

[51]. Sami, qamar and Khalid. (2011). Exploring the leadership terrain. Journal of economics and behavioral studies, PP 3(3) 185-189.

[52]. Shah, A. (2012). The Foundation of Successful Strategy Implementation: Overcoming The Obstacles. Global Business Review, , pp 2(6), 293-307.

[53]. Shanghverzy. (2003). Research Methodology. Theory and Practice. International journal .

[54]. Sterling, J. (2003). Translating Strategy into effective Implementation; Dispelling the Myths and Highlighting what works, Strategy and Leadership. . Strategic Management Journal, Vol. 12 , pp.34-9.
[55]. Taylor, B. (2007). The new strategic leadership bringing changes, getting results. (1st Ed.). Strategic Environment handbook. London: Pitman.

[56]. Thompson, A., Strickland, A. and Gamble, J. (2010). Crafting and Executing Strategy. New York: : McGraw Hill/Irwin.

[57]. Wheelen, T. and Hunger, D. (2008 ). Strategic Management and Business Policy (1 1 th $^{\text {th }}$ Edition). .England: Prentice Hall.

[58]. Wiggill, M. (2011). Strategic communication management in the non-profit sector: a simplified model. . Journal of Public Affairs (14723891), , pp 11(4), 226-235.

[59]. Yamane, T. (1967. ). Statistics, An Introductory Analysis, 2nd Ed. USA: New York: Harper and Row.

Kirabo Mary

MBA Student Mount Kenya University, Rwanda

Francis Mwangi Waweru

Lecturer, Mount Kenya University, Rwanda

fmwangi@mku.ac.ke

Dr. Claude Rusibana, PhD.

Senior Lecturer, Mount Kenya University, Rwanda crusibana@mku.ac.ke

\section{Correspondent Author:}

Kirabo Mary

MBA Student Mount Kenya University, Rwanda

Marykirabo357@yahoo.com 